\title{
Polymer-based dental filling materials placed during pregnancy and risk to the foetus
}

Trine Lise Lundekvam Berge ${ }^{1,2^{*}}$ (D) Gunvor Bentung Lygre ${ }^{1}$, Stein Atle Lie ${ }^{3}$ and Lars Björkman ${ }^{1,3}$

\begin{abstract}
Background: Tooth-coloured polymer-based dental filling materials are currently the first choice for dental restorative treatment in many countries. However, there are some concerns about their safety. It has been shown that substances known as endocrine disrupters, which might pass through the placental barrier, are released from these materials within the first hours after curing. Thus, the placement of polymer-based dental fillings in pregnant women may put the vulnerable foetus at risk. Large epidemiological studies exploring the risk of having polymerbased dental materials placed during pregnancy are lacking. The aim of this study was to investigate the association between the placement of polymer-based dental fillings during pregnancy and adverse birth outcomes.

Methods: This study is based on data from the large Norwegian Mother and Child Cohort Study (MoBa). The information about dental treatment during pregnancy was obtained from questionnaires sent to the participating women during weeks 17 and 30 of pregnancy. Reported placement of "white fillings" was used as exposure marker for having received polymer-based dental filling materials. Only singleton births were included in the present study. Data were linked to the Medical Birth Registry of Norway. Logistic regression models that included the mother's age, level of education, body mass index, parity, and smoking and alcohol consumption during pregnancy were used to estimate the odds ratio (OR) and 95\% confidence interval (CI). Different adverse birth outcomes were of interest in the present study.
\end{abstract}

Results: Valid data were available from 90,886 pregnancies. Dentist consultation during pregnancy was reported by 33,727 women, 10,972 of whom had white fillings placed. The adjusted logistic regression models showed no statistically significant association between having white dental fillings placed during pregnancy and stillbirth, malformations, preterm births, and low or high birth weight.

Conclusions: In this study, women who reported white fillings placed during pregnancy had no increased risk for adverse birth outcomes compared with women who did not consult a dentist during pregnancy. Thus, our findings do not support the hypothesis of an association between placement of polymer-based fillings during pregnancy and adverse birth outcomes.

Keywords: Polymer-based dental filling materials, Pregnancy, Adverse birth outcomes, Congenital malformation, Birth weight, Stillbirth, Premature birth, Bisphenol A, BPA, The Norwegian mother and child cohort study

\footnotetext{
*Correspondence: trbe@norceresearch.no

'Dental Biomaterials Adverse Reaction Unit, Uni Research Health, Bergen,

Norway

${ }^{2}$ Oral Health Centre of Expertise in Western Norway, Bergen, Hordaland,

Norway

Full list of author information is available at the end of the article
}

(c) The Author(s). 2018 Open Access This article is distributed under the terms of the Creative Commons Attribution 4.0 International License (http://creativecommons.org/licenses/by/4.0/), which permits unrestricted use, distribution, and reproduction in any medium, provided you give appropriate credit to the original author(s) and the source, provide a link to the Creative Commons license, and indicate if changes were made. The Creative Commons Public Domain Dedication waiver (http://creativecommons.org/publicdomain/zero/1.0/) applies to the data made available in this article, unless otherwise stated. 


\section{Background}

Tooth-coloured polymer-based materials are the first choice for dental restorative treatment in many countries $[1,2]$. However, there are concerns about the safety of these materials [3]. Results of in vitro and in vivo studies have shown that substances that potentially could lead to adverse effects in the patient are released from these materials within $24 \mathrm{~h}$ after curing [4-8]. Elution may initially be due to incomplete polymerization $[9,10]$ and contaminants $[11,12]$. The local adverse effects [13] caused by the leachable components are rare [14]. However, the possibility of systemic adverse effects could not be ruled out [15].

The elution of bisphenol A (BPA) has been of particular concern [16]. BPA is a chemical known to be an endocrine disruptor, mimicking oestrogen [17, 18]. Polymer-based dental filling materials may contain BPA as an impurity from the production process of bisphenol-A glycidyl dimethacrylate (Bis-GMA) $[8,11,19,20]$ or, less probable, a degradation product of monomers [12, 21, 22]. Results from animal studies have indicated that BPA has reproductive, developmental and systemic toxic effects [23, 24]. It has been shown that newly placed composite restorations in humans may be associated with short-term elevated BPA levels in both saliva and urine $[4,7]$.

The impact of exposure to BPA on human health remains uncertain. However, data from the literature indicate that exposure to BPA, even at relatively low doses, could potentially result in adverse health effects [15]. Moreover, studies suggest that BPA might pass through the placental barrier [25], and thus, maternal exposure to BPA may offer a potential risk to the vulnerable foetus.

Even though substances with potential toxicity are released from dental polymer-based materials [4, 5], studies exploring the risk of having these materials placed during pregnancy are lacking.

The aim of the present study was to investigate whether the placement of polymer-based dental fillings during pregnancy is associated with adverse birth outcomes including stillbirth, preterm birth, malformations and low or high birth weight.

\section{Methods}

Data from the ongoing Norwegian Mother and Child Cohort Study (MoBa), a prospective population-based cohort study conducted by the Norwegian Institute of Public Health, were used. From 1999 to the end of 2008, pregnant women in Norway were invited to MoBa through a postal invitation in connection with their first routine ultrasound examination. The participation rate was approximately $41 \%$, and the cohort currently comprises more than 108,000 pregnancies, 114,000 children, 95,000 mothers and 75,000 fathers. Written informed consent was obtained from each participant upon recruitment $[26,27]$.

In the present study, data were gathered from two questionnaires that were sent to the participating women in weeks 17 and 30 of pregnancy [28]. Each woman could participate with multiple pregnancies. Only singleton births were included in the present study.

Information about white fillings placed during pregnancy was obtained from the questionnaires sent to the participants in week 30. Reported placement of white fillings was used as exposure marker. The participants reported if they had consulted a dentist during pregnancy ("Have you been to the dentist during this pregnancy? Yes/No") and if so, whether they had received white fillings ("If, yes, did the dentist put in new white fillings? Yes/No").

Women without valid information about dental treatment during pregnancy and those with missing data on birth outcomes were excluded, leaving a study population that included 90,886 pregnancies (Fig. 1).

Information about gender, preterm delivery, stillbirth, malformations, birth weight and mother's age at delivery was obtained from the Medical Birth Registry of Norway (MBRN) [29]. The mother's 11-digit unique personal identification number assigned to every citizen in Norway was used to link data sources. Gestational age was based on ultrasound examination in the 17th week of pregnancy.

Infants were classified as late preterm if they were born between gestational week 33 and 37, and very preterm if they were born before or during the $32 \mathrm{nd}$ gestational week [30, 31]. Infants with a birth weight less than $2500 \mathrm{~g}$ at birth were classified as low-birth weight infants, and infants with a birth weight more than $4000 \mathrm{~g}$ were classified as high-birth weight infants [32].

Maternal body mass index (BMI; $\mathrm{kg} / \mathrm{m}^{2}$ ) was calculated from self-reported pre-pregnancy height and weight. The BMI was categorized according to the WHO classification [33].

Information about parity, defined as the number of former births with a gestational age of 12 weeks or more, was based on data reported by the mothers in the MoBa study and from the MBRN.

Information about education, smoking habits and alcohol consumption during pregnancy was obtained from the first questionnaire completed at approximately the 17 th week.

The present study is based on version 8 of the quality-assured MoBa data files. We defined dental treatment during pregnancy as follows: participants who did not consult a dentist during pregnancy (reference category); participants who consulted a dentist but had no white fillings placed; and participants who consulted a dentist and had white fillings placed (Fig. 1). 


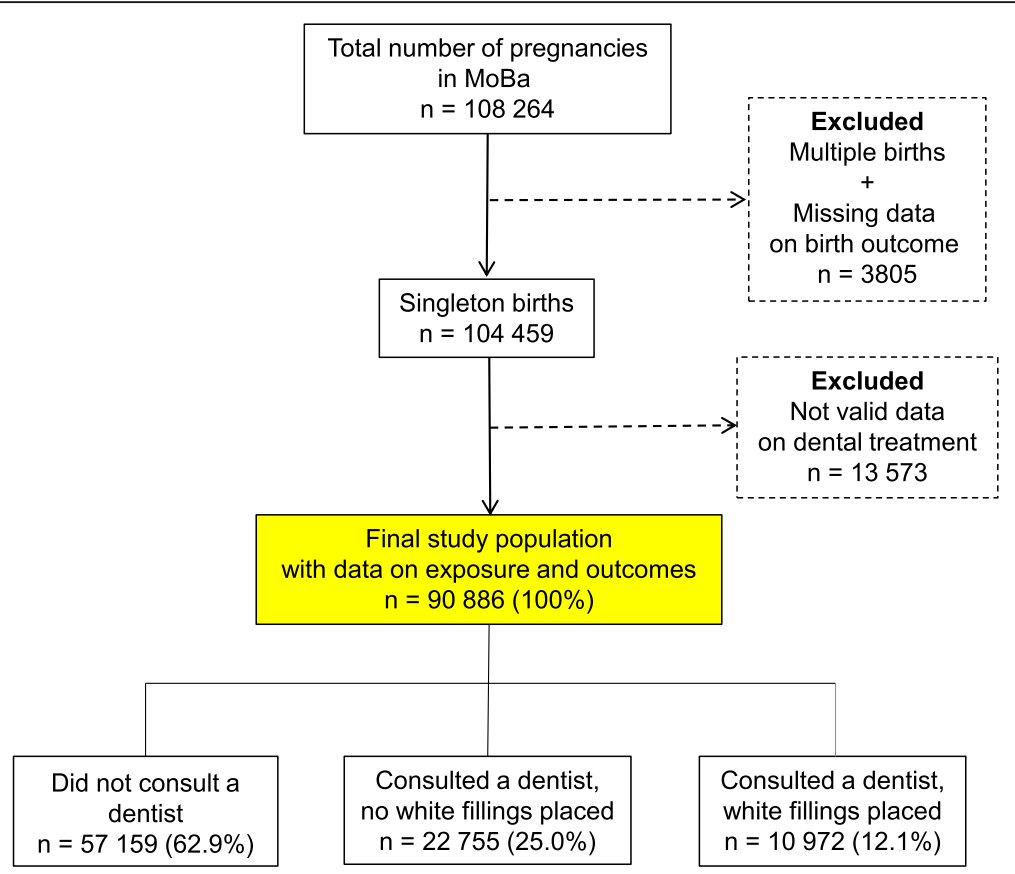

Fig. 1 Flowchart showing number of participants included in the study and the groups available for analysis

Infants were defined as small for gestational age (SGA) if the weight at birth was less than the 10th percentile for gestational age and large for gestational age (LGA) if they were larger than the 90th percentile. Very small for gestational age was defined as weight below the 2.5th percentile [34].

The odds ratio (OR) with a $95 \%$ confidence interval was calculated using logistic regression. The OR was adjusted for maternal age $(\leq 19,20-24,25-29,30-34$, $35-39$, 40+ years), length of education $(\leq 12,13-16$, $\geq 17$ years $)$, pre-pregnancy BMI $(<18.5,18.5-24.9,25.0$ $29.9,30.0-34.9,35.0-39.9, \geq 40 \mathrm{~kg} / \mathrm{m}^{2}$ ), parity (first, second and more), smoking during pregnancy (never, occasionally, daily) and alcohol consumption during pregnancy (never, less than once a week, once a week, more than once a week).

Analyses were performed using IBM-SPSS (IBM Corp. Released 2016. IBM SPSS Statistics for Windows, Version 24.0, Armonk, NY, USA: IBM Corp.). p-values less than 0.05 were considered statistically significant.

The MoBa cohort study obtained a license from the Norwegian Data Inspectorate, and this research project was approved by the Regional Ethics Committee for Medical Research (REC South-East D, 2011/727).

\section{Results}

Dentist consultation during pregnancy was reported by 33,727 women, and of these, 10,972 had white fillings placed (Fig. 1). Detailed descriptive information regarding the characteristics of the participants is included in
Table 1. Of the included pregnancies, $204(0.2 \%)$ resulted in a stillbirth. The overall proportion of malformation was $4.8 \%$, and the proportion of very preterm births and late preterm births was 0.6 and $3.8 \%$, respectively (Table 2).

Compared to the reference group, there was no statistically significant increased risk for any adverse birth outcomes for participants who had consulted a dentist during pregnancy without having white fillings placed or for those who had white fillings placed (Table 3).

Separate analyses by gender showed that girls born to mothers who had white fillings placed during pregnancy had an increased risk of being small for gestational age (below the 10th percentile) compared to the reference group. The unadjusted OR was 1.14 (95\% CI 1.01-1.28; $p=0.029)$ while after adjustment for potential confounders, the OR was reduced and not statistically significant $(\mathrm{OR}=1.10,95 \%$ CI 0.97-1.24; Table 3).

Boys born to mothers who received white fillings during pregnancy had a slightly increased risk of being born late preterm compared to the boys born in the reference group. The unadjusted OR was 1.16 (95\% CI 1.01-1.34; $p=0.041$ ), and the adjusted OR was 1.13 (95\% CI $0.98-$ $1.31 ; p=0.082$; Table 3).

\section{Discussion}

The aim of the present study was to investigate whether the placement of polymer-based dental fillings during pregnancy was associated with outcomes including stillbirth, preterm delivery, malformations, and low or high 
Table 1 Characteristics of the participants related to dental treatment during pregnancy $(n=90,886)$

\begin{tabular}{|c|c|c|c|c|}
\hline & Did not consult a dentist & $\begin{array}{l}\text { Consulted a dentist, } \\
\text { no white fillings placed }\end{array}$ & $\begin{array}{l}\text { Consulted a dentist, } \\
\text { white filling placed }\end{array}$ & Total \\
\hline Number of participating pregnancies, $n(\%)$ & $57,159(62.9)$ & $22,755(25.0)$ & $10,972(12.1)$ & $90,886(100)$ \\
\hline \multicolumn{5}{|l|}{ Maternal age (years), $n(\%)$} \\
\hline$\leq 19$ & $525(0.9)$ & $207(0.9)$ & $127(1.2)$ & $859(0.9)$ \\
\hline $20-24$ & $6056(10.6)$ & $1767(7.8)$ & $1195(10.9)$ & $9018(9.9)$ \\
\hline $25-29$ & $19,288(33.7)$ & $7159(31.5)$ & $3686(33.6)$ & $30,133(33.2)$ \\
\hline $30-34$ & $21,928(38.4)$ & $9273(40.8)$ & $3990(36.4)$ & $35,191(38.7)$ \\
\hline $35-39$ & $8315(14.5)$ & $3856(16.9)$ & $1711(15.6)$ & $13,882(15.3)$ \\
\hline$\geq 40$ & $1047(1.8)$ & $493(2.2)$ & $263(2.4)$ & $1803(2.0)$ \\
\hline \multicolumn{5}{|l|}{ Maternal pre-pregnant Body Mass Index, $n(\%)$} \\
\hline$<18.5$ & $1663(2.9)$ & $660(2.9)$ & $319(2.9)$ & $2642(2.9)$ \\
\hline $18.5-24.9$ & $36,021(63.0)$ & $14,956(65.7)$ & $6655(60.7)$ & $57,632(63.4)$ \\
\hline $25.0-29.9$ & $12,003(21.0)$ & $4542(20.0)$ & $2443(22.3)$ & $18,988(20.9)$ \\
\hline $30.0-34.9$ & $3837(6.7)$ & $1402(6.2)$ & $842(7.7)$ & $6081(6.7)$ \\
\hline $35.0-39.9$ & $1091(1.9)$ & $354(1.6)$ & $232(2.1)$ & $1677(1.8)$ \\
\hline$\geq 40$ & $341(0.6)$ & $124(0.5)$ & $68(0.6)$ & $533(0.6)$ \\
\hline Missing & $2203(3.9)$ & $717(3.2)$ & $413(3.8)$ & $3333(3.7)$ \\
\hline \multicolumn{5}{|l|}{ Parity, $n(\%)$} \\
\hline Para 0 (first pregnancy) & $25,428(44.5)$ & $10,897(47.9)$ & $4836(44.1)$ & $41,161(45.3)$ \\
\hline Para 1+ (second pregnancy or more) & $31,731(55.5)$ & $11,858(52.1)$ & $6136(55.9)$ & $49,725(54.7)$ \\
\hline \multicolumn{5}{|l|}{ Maternal education, $n$ (\%) } \\
\hline$\leq 12$ years & $18,849(33.0)$ & $6831(30.0)$ & $4177(38.1)$ & $29,857(32.9)$ \\
\hline $13-16$ years & $22,042(38.6)$ & $9226(40.5)$ & 4018 (36.6) & $35,286(38.8)$ \\
\hline$\geq 17$ years & $12,725(22.3)$ & $5366(23.6)$ & $2097(19.1)$ & $20,188(22.2)$ \\
\hline Missing & $3543(6.2)$ & $1332(5.9)$ & $680(6.2)$ & $5555(6.1)$ \\
\hline \multicolumn{5}{|l|}{ Smoking during pregnancy, $n$ (\%) } \\
\hline Never & $45,831(80.2)$ & $18,208(80.0)$ & $8420(76.7)$ & $72,459(79.7)$ \\
\hline Occasionally & $1421(2.5)$ & $567(2.5)$ & $374(3.4)$ & $2362(2.6)$ \\
\hline Daily & $2848(5.0)$ & $968(4.3)$ & $821(7.5)$ & $4637(5.1)$ \\
\hline Missing & 7059 (12.3) & $3012(13.2)$ & $1357(12.4)$ & $11,428(12.6)$ \\
\hline \multicolumn{5}{|l|}{ Alcohol during pregnancy, n (\%) } \\
\hline Never & $42,203(73.8)$ & $16,731(73.5)$ & $7834(71.4)$ & $66,768(73.5)$ \\
\hline Less than once a week & $5709(10.0)$ & $2512(11.0)$ & $1251(11.4)$ & $9472(10.4)$ \\
\hline Once a week & $233(0.4)$ & $100(0.4)$ & $46(0.4)$ & $379(0.4)$ \\
\hline More than once a week & $39(0.1)$ & $25(0.1)$ & $6(0.1)$ & $70(0.1)$ \\
\hline Missing & $8975(15.7)$ & $3387(14.9)$ & $1835(16.7)$ & $14,197(15.6)$ \\
\hline
\end{tabular}

Body Mass Index = weight $(\mathrm{kg}) /$ height $^{2}(\mathrm{~m})^{2}$

birth weight. No evidence of an increased risk of adverse birth outcomes after placement of white fillings during pregnancy was found. Gender-specific analyses showed generally similar results for girls and boys analysed together.

The main strengths of the present study are the overall large sample size and the large number of participants who had white fillings placed. These large numbers enabled us to study even rare birth outcomes. Furthermore, the prospective design of the study reduced the risk for recall bias. Additionally, the information on health-related and lifestyle data that was derived from both the MBRN and the MoBa questionnaires enabled us to control for some potential confounding factors.

To the best of our knowledge, the present study is the first to investigate potential associations between 
Table 2 Birth outcomes by dental treatment during pregnancy $(n=90,886)$

\begin{tabular}{|c|c|c|c|c|}
\hline & Did not consult a dentist & $\begin{array}{l}\text { Consulted a dentist, } \\
\text { no white fillings placed }\end{array}$ & $\begin{array}{l}\text { Consulted a dentist, } \\
\text { white filling placed }\end{array}$ & Total \\
\hline Number of boys, $n(\%)$ & $29,387(51.4)$ & $11,607(51.0)$ & $5582(50.9)$ & $46,576(51.2)$ \\
\hline \multicolumn{5}{|l|}{ Number of preterm births, $n(\%)$} \\
\hline Very preterm births ( $\leq 32$ weeks) & $337(0.6)$ & $124(0.5)$ & $65(0.6)$ & $526(0.6)$ \\
\hline Late preterm births (33-36 weeks) & $2150(3.8)$ & $884(3.9)$ & $454(4.1)$ & $3488(3.8)$ \\
\hline \multicolumn{5}{|l|}{ Mean birth weight (g) } \\
\hline Mean birth weight (SD) & $3611(546)$ & $3603(538)$ & 3607 (549) & $3608(544)$ \\
\hline \multicolumn{5}{|l|}{ Number of children with low birth weight, $n$ (\%) } \\
\hline Low birth weight $(<2500 \mathrm{~g})$ & $1465(2.6)$ & $576(2.5)$ & $290(2.6)$ & $2331(2.6)$ \\
\hline Small for gestational age (SGA) 10 percentile & $3660(6.4)$ & $1475(6.5)$ & $726(6.6)$ & $5861(6.5)$ \\
\hline Small for gestational age (SGA) 2.5 percentile & $793(1.4)$ & $293(1.3)$ & $145(1,3)$ & $1231(1.4)$ \\
\hline \multicolumn{5}{|l|}{ Number of children with high birth weight, $n(\%)$} \\
\hline High birth weight children (> $4000 \mathrm{~g}$ ) & $12,515(21.9)$ & $4905(21.6)$ & $2390(21.8)$ & $19,810(21.8)$ \\
\hline Large for gestational age (LGA) 10 percentile & $6633(11.7)$ & $2557(11.3)$ & $1285(11.8)$ & $10,475(11.6)$ \\
\hline Large for gestational age (LGA) 2.5 percentile & $2110(3.7)$ & 809 (3.6) & $418(3.8)$ & $3337(3.7)$ \\
\hline Number of children with malformation, $n(\%)$ & $2697(4.7)$ & $1108(4.9)$ & $519(4.7)$ & $4324(4.8)$ \\
\hline Number of stillbirths, $n$ (\%) & $125(0.2)$ & $49(0.2)$ & $30(0.3)$ & $204(0.2)$ \\
\hline
\end{tabular}

polymer-based fillings placed during pregnancy and birth outcomes. Michalowicz et al. found no significant associations between adverse pregnancy outcomes and periodontal treatment, the use of anaesthetic during nonsurgical periodontal treatment, treatment including temporary and permanent restorations, endodontic therapy, and extractions [35]. These results are in agreement with our findings. However, in the study of Michalowicz et al., the type of restorative material was not specified. Thus, the results are not directly comparable.

A limitation of the MoBa study is the low response rate, with a possible self-selection of the healthiest women. The MoBa has an underrepresentation of young mothers $(<25$ years). The participants have a higher level of education and are more likely to be non-smokers than the general population of pregnant women in Norway [36].

However, self-selection to the cohort is not a validity problem in studies of associations between exposure and outcomes [36].

The MoBa study is based on questionnaires filled in by the participating women. To achieve reliable answers from all participants in this large cohort, an effort was made to make the questions as easy and achievable as possible. Thus, information about dental treatment is sparse. Detailed information about the type and manufacturer of the polymer-based filling material and size and number of fillings placed, would be of interest. However, to obtain accurate information about this, access to dental records would be needed. In large epidemiological studies, like the MoBa study, access to updated dental records would be unfeasible. Accordingly, reliable knowledge about the number and size of possible pre-existing composite restorations is lacking. Since leakage of BPA from existing polymer-based restorative materials is very low compared with other sources [37], this information would most likely be of minor importance.

The participants were asked if they had received "white fillings" during pregnancy. In Norway, white fillings would practically be the same as polymer-based restorative fillings or so called polymer-based or resin-based composites. However, the term "white fillings" may include materials like resin-modified cements, compomers and water-based glass ionomer cements (GIC). In the period of this study, the vast majority of Norwegian dentists used polymer-based filling materials when restoring cavities in adults. Kopperud et al. described management of occlusal caries in adults by Norwegian dentists in 2009 and stated that polymer-based composite was the preferred restorative material (91.9\%) [38]. In the same study the use of other filling materials was reported to be less than $4 \%$. This is in accordance with another study examining treatment concept for approximal caries in Norway [39]. In 2009 polymer-based filling material was preferred by $94.9 \%$ of the responding dentists. Preference for other filling materials was: $1.1 \%$ compomer, $1.1 \%$ GIC, $0.5 \%$ resin-modified GIC and $1.8 \%$ a combination of resin composite and GIC [39]. In 1997, 2 years before recruitment started in MoBa, Norwegian data showed that approximately $70 \%$ of the tooth-coloured fillings placed in adults were polymer-based [40]. 
Table 3 Crude and adjusted odds ratio (OR) and confidence interval (CI) for adverse birth outcomes related to dental treatment during pregnancy. (Reference category: Women who did not consult a dentist, $O R=1$ )

\begin{tabular}{|c|c|c|c|}
\hline & & $\begin{array}{l}\text { Consulted a dentist, no white } \\
\text { fillings placed OR }(95 \% \mathrm{Cl})\end{array}$ & $\begin{array}{l}\text { Consulted a dentist, white } \\
\text { filling placed OR ( } 95 \% \mathrm{Cl})\end{array}$ \\
\hline \multicolumn{4}{|c|}{ Very preterm birth ( $\leq 32$ weeks) } \\
\hline \multirow[t]{2}{*}{ Girls } & Crude & $0.96(0.71-1.30)$ & $0.91(0.60-1.37)$ \\
\hline & Adjusted & $0.94(0.69-1.27)$ & $0.88(0.58-1.33)$ \\
\hline \multirow[t]{2}{*}{ Boys } & Crude & $0.91(0.69-1.21)$ & $1.08(0.76-1.53)$ \\
\hline & Adjusted & $0.88(0.67-1.17)$ & $1.02(0.72-1.45)$ \\
\hline \multirow[t]{2}{*}{ All } & Crude & $0.92(0.75-1.14)$ & $1.01(0.77-1.31)$ \\
\hline & Adjusted & $0.90(0.73-1.11)$ & $0.97(0.74-1.26)$ \\
\hline \multicolumn{4}{|c|}{ Late preterm birth (33-36 weeks) } \\
\hline \multirow[t]{2}{*}{ Girls } & Crude & $1.00(0.89-1.13)$ & $1.05(0.90-1.22)$ \\
\hline & Adjusted & $1.00(0.89-1.12)$ & $1.03(0.88-1.19)$ \\
\hline \multirow[t]{2}{*}{ Boys } & Crude & $1.06(0.95-1.18)$ & $1.16^{*}(1.01-1.34)$ \\
\hline & Adjusted & $1.05(0.94-1.18)$ & $1.14(0.99-1.31)$ \\
\hline \multirow[t]{2}{*}{ All } & Crude & $1.03(0.96-1.12)$ & $1.10(1.00-1.23)$ \\
\hline & Adjusted & $1.03(0.95-1.11)$ & $1.08(0.97-1.20)$ \\
\hline \multicolumn{4}{|c|}{ Low birth weight (<2500 g) } \\
\hline \multirow[t]{2}{*}{ Girls } & Crude & $1.01(0.88-1.51)$ & $1.03(0.86-1.23)$ \\
\hline & Adjusted & $0.98(0.86-1.12)$ & $0.99(0.83-1.18)$ \\
\hline \multirow[t]{2}{*}{ Boys } & Crude & $0.96(0.84-1.11)$ & $1.03(0.86-1.24)$ \\
\hline & Adjusted & $0.94(0.82-1.09)$ & $0.99(0.83-1.19)$ \\
\hline \multirow[t]{2}{*}{ All } & Crude & $0.99(0.90-1.09)$ & $1.03(0.91-1.17)$ \\
\hline & Adjusted & $0.96(0.87-1.06)$ & $0.99(0.87-1.13)$ \\
\hline \multicolumn{4}{|c|}{ Small for gestational age (SGA) 10 percentile } \\
\hline \multirow[t]{2}{*}{ Girls } & Crude & $1.07(0.97-1.17)$ & $1.14^{*}(1.01-1.28)$ \\
\hline & Adjusted & $1.03(0.94-1.13)$ & $1.10(0.97-1.24)$ \\
\hline \multirow[t]{2}{*}{ Boys } & Crude & $0.97(0.89-1.05)$ & $0.95(0.85-1.07)$ \\
\hline & Adjusted & $0.92(0.84-1.00)$ & $0.93(0.83-1.04)$ \\
\hline \multirow[t]{2}{*}{ All } & Crude & $1.01(0.95-1.08)$ & $1.04(0.95-1.13)$ \\
\hline & Adjusted & $0.97(0.91-1.03)$ & $1.00(0.92-1.09)$ \\
\hline \multicolumn{4}{|c|}{ Very small for gestational age (SGA) 2.5 percentile } \\
\hline \multirow[t]{2}{*}{ Girls } & Crude & $0.86(0.71-1.06)$ & $1.04(0.81-1.34)$ \\
\hline & Adjusted & $0.84(0.68-1.03)$ & $0.97(0.75-1.25)$ \\
\hline \multirow[t]{2}{*}{ Boys } & Crude & $0.98(0.82-1.17)$ & $0.88(0.68-1.13)$ \\
\hline & Adjusted & $0.93(0.77-1.11)$ & $0.84(0.65-1.08)$ \\
\hline \multirow[t]{2}{*}{ All } & Crude & $0.93(0.81-1.06)$ & $0.95(0.80-1.14)$ \\
\hline & Adjusted & $0.89(0.77-1.02)$ & $0.90(0.75-1.08)$ \\
\hline \multicolumn{4}{|c|}{ High birth weight (> $4000 \mathrm{~g}$ ) } \\
\hline \multirow[t]{2}{*}{ Girls } & Crude & $0.99(0.94-1.05)$ & $0.98(0.91-1.06)$ \\
\hline & Adjusted & $1.03(0.97-1.09)$ & $0.98(0.91-1.06)$ \\
\hline \multirow[t]{2}{*}{ Boys } & Crude & $0.98(0.93-1.03)$ & $1.01(0.94-1.07)$ \\
\hline & Adjusted & $1.01(0.96-1.06)$ & $1.00(0.93-1.07)$ \\
\hline \multirow[t]{2}{*}{ All } & Crude & $0.98(0.94-1.02)$ & $0.99(0.95-1.04)$ \\
\hline & Adjusted & $1.01(0.98-1.05)$ & $0.99(0.94-1.04)$ \\
\hline
\end{tabular}


Table 3 Crude and adjusted odds ratio (OR) and confidence interval (CI) for adverse birth outcomes related to dental treatment during pregnancy. (Reference category: Women who did not consult a dentist, $\mathrm{OR}=1$ ) (Continued)

\begin{tabular}{|c|c|c|c|}
\hline & & $\begin{array}{l}\text { Consulted a dentist, no white } \\
\text { fillings placed OR ( } 95 \% \mathrm{Cl})\end{array}$ & $\begin{array}{l}\text { Consulted a dentist, white } \\
\text { filling placed OR }(95 \% \text { Cl) }\end{array}$ \\
\hline \multicolumn{4}{|c|}{ Large for gestational age (LGA) 10 percentile } \\
\hline \multirow[t]{2}{*}{ Girls } & Crude & $0.96(0.90-1.02)$ & $0.99(0.91-1.08)$ \\
\hline & Adjusted & $1.00(0.93-1.07)$ & $0.98(0.90-1.08)$ \\
\hline \multirow[t]{2}{*}{ Boys } & Crude & $0.97(0.90-1.04)$ & $1.03(0.94-1.13)$ \\
\hline & Adjusted & $1.01(0.94-1.08)$ & $1.01(0.93-1.11)$ \\
\hline \multirow[t]{2}{*}{ All } & Crude & $0.96(0.92-1.01)$ & $1.01(0.95-1.08)$ \\
\hline & Adjusted & $1.01(0.96-1.06)$ & $1.00(0.94-1.06)$ \\
\hline \multicolumn{4}{|c|}{ Large for gestational age (LGA) 2.5 percentile } \\
\hline \multirow[t]{2}{*}{ Girls } & Crude & $0.97(0.87-1.09)$ & $1.01(0.87-1.17)$ \\
\hline & Adjusted & $1.02(0.91-1.15)$ & $0.99(0.86-1.15)$ \\
\hline \multirow[t]{2}{*}{ Boys } & Crude & $0.95(0.84-1.07)$ & $1.06(0.90-1.24)$ \\
\hline & Adjusted & $0.98(0.87-1.11)$ & $1.03(0.88-1.20)$ \\
\hline \multirow[t]{2}{*}{ All } & Crude & $0.96(0.88-1.04)$ & $1.03(0.93-1.15)$ \\
\hline & Adjusted & $1.00(0.92-1.09)$ & $1.01(0.91-1.12)$ \\
\hline \multicolumn{4}{|c|}{ Malformation } \\
\hline \multirow[t]{2}{*}{ Girls } & Crude & $1.02(0.92-1.14)$ & $0.99(0.86-1.15)$ \\
\hline & Adjusted & $1.00(0.90-1.12)$ & $1.00(0.86-1.15)$ \\
\hline \multirow[t]{2}{*}{ Boys } & Crude & $1.05(0.95-1.15)$ & $1.01(0.89-1.15)$ \\
\hline & Adjusted & $1.03(0.94-1.14)$ & $1.00(0.88-1.14)$ \\
\hline \multirow[t]{2}{*}{ All } & Crude & $1.03(0.96-1.11)$ & $1.00(0.91-1.10)$ \\
\hline & Adjusted & $1.02(0.95-1.09)$ & $1.00(0.91-1.10)$ \\
\hline \multicolumn{4}{|c|}{ Stillbirth } \\
\hline \multirow[t]{2}{*}{ Girls } & Crude & $0.96(0.59-1.55)$ & $1.20(0.67-2.15)$ \\
\hline & Adjusted & $0.92(0.57-1.50)$ & $1.16(0.64-2.07)$ \\
\hline \multirow[t]{2}{*}{ Boys } & Crude & $0.97(0.61-1.54)$ & $1.30(0.75-2.24)$ \\
\hline & Adjusted & $0.95(0.60-1.51)$ & $1.22(0.70-2.11)$ \\
\hline \multirow[t]{2}{*}{ All } & Crude & $0.98(0.71-1.37)$ & $1.25(0.84-1.86)$ \\
\hline & Adjusted & $0.96(0.69-1.33)$ & $1.18(0.79-1.76)$ \\
\hline
\end{tabular}

The OR was adjusted for mothers age ( $\leq 19,20-24,25-29,30-34,35-39,40+)$, parity $(0,1$ or more previous viable pregnancies), education ( $\leq 12$ years, $13-16$ years, $\geq 17$ years), pre-pregnancy body mass index (<18.5, 18.5-24.9, 25.0-29.9, 30.0-34.9, 35.0-39.9, $\geq 40$ ), smoking (never, occasionally, daily) and alcohol consumption during pregnancy (never, less than once a week, once a week, more than once a week). ${ }^{*} p<0.05$

The participants answered questions regarding dental treatment during the first 30 weeks of pregnancy but were not asked to specify in which week of pregnancy they visited the dentist. Hence, a limitation is that we could not study if treatment with polymer-based filling materials could be a factor of importance at specific time windows during pregnancy. The severity of the effects of prenatal exposure to toxic agents appears to be influenced by the degree and timing of the exposure during gestation [41]. Some teratogens cause damage only during specific days or weeks early in pregnancy, when a particular part of the body is formed [41]. A well-known example is the thalidomide-tragedy in the late 1950 s and the early 1960s, where the medication taken during days 20-36 after fertilization resulted in serious malformations of the foetus [42, 43].

Some women with the need for dental treatment do not seek or do not receive dental care during pregnancy [44]. This may, in part, be due to their concerns about the potential risk to the foetus, as well as dentists and other health care providers' attitudes and beliefs about the safety of dental treatment during pregnancy [44].

The findings from the present study, including more than 90,000 pregnancies, are reassuring. However, taken the limitations of a prospective cohort study into account, these findings could be corroborated in case 
control studies. Thus, access to dental records and thereby accurate and detailed information regarding dental treatment could be possible to obtain.

\section{Conclusion}

In this study, women who had white fillings placed during pregnancy had no increased risk for adverse birth outcomes compared with women who did not consult a dentist during pregnancy. Thus, our findings do not support the hypothesis of an association between placement of polymer-based fillings during pregnancy and adverse birth outcomes.

\section{Abbreviations}

Bis-GMA: Bisphenol-A glycidyl dimethacrylate; BMI: Body mass index; BPA: Bisphenol A; LGA: Large for gestational age; MBRN: Medical Birth Registry of Norway; MoBa: the Norwegian Mother and Child Cohort Study; SGA: Small for gestational age; WHO: World Health Organization

\section{Acknowledgements}

The Norwegian Mother and Child Cohort Study is supported by the Norwegian Ministry of Health and Care Services and the Ministry of Education and Research, NIH/NINDS (grant no.1 UO1 NS 047537-01 and grant no.2 UO1 NS 047537-06A1). We are grateful to all the participating families in Norway who take part in this on-going cohort study.

\section{Funding}

The Norwegian Dental Biomaterials Adverse Reaction Unit and the Oral Health Centre of Expertise in Western Norway are funded by the Norwegian Ministry of Health and Care Services.

\section{Availability of data and materials}

Due to data protection regulations no data can be shared. Information about data access from the Norwegian Mother and Child Cohort Study is given by the Norwegian Institute of Public Health [45].

\section{Authors' contributions}

GBL and LB conceptualized the study, critically reviewed the results of the analyses, reviewed and revised the manuscript. TLLB carried out the analyses, drafted the initial manuscript and coordinated the editing. SAL critically reviewed the results of analyses, reviewed and revised the manuscript. All authors approved the final manuscript as submitted.

\section{Ethics approval and consent to participate}

The MoBa study was conducted according to the guidelines in the Declaration of Helsinki. The Regional Committee for Medical and Health Research Ethics in South-East Norway and the Norwegian Data Inspectorate approved the study. All MoBa participants provided written informed consent before enrolment into the study, permitting repeated assessment, the use and publication of data, and linkage to other health registries. The MoBa study protocol (revised October 2012) including patient consent form is available from Norwegian Institute of Public Health [46]. The present study was approved by the Regional Ethics Committee for medical research (REC South-East D, 2011/727).

\section{Consent for publication}

Not applicable.

\section{Competing interests}

The authors declare that they have no competing interests.

\section{Publisher's Note}

Springer Nature remains neutral with regard to jurisdictional claims in published maps and institutional affiliations.

\section{Author details}

'Dental Biomaterials Adverse Reaction Unit, Uni Research Health, Bergen, Norway. ${ }^{2}$ Oral Health Centre of Expertise in Western Norway, Bergen, Hordaland, Norway. ${ }^{3}$ Department of Clinical Dentistry, University of Bergen, Bergen, Norway.

Received: 19 January 2018 Accepted: 13 August 2018

Published online: 22 August 2018

\section{References}

1. Alexander G, Hopcraft MS, Tyas MJ, Wong RH. Dentists' restorative decisionmaking and implications for an 'amalgamless' profession. Part 1: a review. Aust Dent J. 2014;59:408-19. https://doi.org/10.1111/adj.12209.

2. Eklund SA. Trends in dental treatment, 1992 to 2007. J Am Dent Assoc. 2010;141:391-9. https://www.ncbi.nlm.nih.gov/pubmed/20354088

3. SCENIHR (Scientific Committee on Emerging and Newly-Identified Health Risks). Opinion on the safety of dental amalgam and alternative dental restoration materials for patients and users (update), 29 April. European commission. DG Health and Food Safety. 2015:2015. http://ec.europa.eu/ health/sites/health/files/scientific_committees/emerging/docs/scenihr_O_ 046.pdf. Accessed 14 Dec 2017

4. Kingman A, Hyman J, Masten SA, Jayaram B, Smith C, Eichmiller F, et al. Bisphenol A and other compounds in human saliva and urine associated with the placement of composite restorations. J Am Dent Assoc. 2012;143:1292-302. http://www.ncbi.nlm.nih.gov/pubmed/23204083

5. Michelsen VB, Kopperud HB, Lygre GB, Bjorkman L, Jensen E, Kleven IS, et al. Detection and quantification of monomers in unstimulated whole saliva after treatment with resin-based composite fillings in vivo. Eur J Oral Sci. 2012;120:89-95. https://doi.org/10.1111/j.16000722.2011.00897.x.

6. Sevkusic M, Schuster L, Rothmund L, Dettinger K, Maier M, Hickel R, et al. The elution and breakdown behavior of constituents from various lightcured composites. Dent Mater. 2014;30:619-31. https://doi.org/10.1016/j. dental.2014.02.022.

7. Maserejian NN, Trachtenberg FL, Wheaton OB, Calafat AM, Ranganathan $\mathrm{G}, \mathrm{Kim} \mathrm{HY}$, et al. Changes in urinary bisphenol a concentrations associated with placement of dental composite restorations in children and adolescents. J Am Dent Assoc. 2016; https://doi.org/10.1016/j.adaj. 2016.02.020.

8. Van Landuyt KL, Nawrot T, Geebelen B, De Munck J, Snauwaert J, Yoshihara $\mathrm{K}$, et al. How much do resin-based dental materials release? A metaanalytical approach. Dent Mater. 2011;27:723-47. https://doi.org/10.1016/j. dental.2011.05.001.

9. Durner J, Obermaier J, Draenert M, llie N. Correlation of the degree of conversion with the amount of elutable substances in nano-hybrid dental composites. Dent Mater. 2012;28:1146-53. https://doi.org/10.1016/j.dental. 2012.08.006

10. Ferracane JL. Elution of leachable components from composites. J Oral Rehabil. 1994;21:441-52. https://www.ncbi.nlm.nih.gov/pubmed/7965355

11. American Dental Association Council on Scientific Affairs. Determination of bisphenol a released from resin-based composite dental restoratives. American Dental Association Professional Product Review. 2014;9(3). http://www.ada.org/en/publications/ada-professional-product-review-ppr. Accessed 5 Sept 2014

12. Schmalz G, Preiss A, Arenholt-Bindslev D. Bisphenol-A content of resin monomers and related degradation products. Clin Oral Investig. 1999:3:114-9. https://www.ncbi.nlm.nih.gov/pubmed/10803121

13. Schedle A, Ortengren U, Eidler N, Gabauer M, Hensten A. Do adverse effects of dental materials exist? What are the consequences, and how can they be diagnosed and treated? Clin Oral Implants Res. 2007;18(Suppl 3):232-56. https://doi.org/10.1111/j.1600-0501.2007.01481.x.

14. Bakopoulou A, Papadopoulos T, Garefis P. Molecular toxicology of substances released from resin-based dental restorative materials. Int I Mol Sci. 2009;10:3861-99. https://doi.org/10.3390/ijms10093861.

15. Rochester JR. Bisphenol a and human health: a review of the literature. Reprod Toxicol. 2013;42:132-55. https://doi.org/10.1016/j.reprotox.2013. 08.008.

16. Fleisch AF, Sheffield PE, Chinn C, Edelstein BL, Landrigan PJ. Bisphenol a and related compounds in dental materials. Pediatrics. 2010;126:760-8. https://doi.org/10.1542/peds.2009-2693. 
17. Schug T, Janesick A, Blumberg B, Heindel JJ. Endocrine disrupting chemicals and disease susceptibility. J Steroid Biochem Mol Biol. 2011;127:204-15. https://doi.org/10.1016/j.jsbmb.2011.08.007.

18. Crain DA, Eriksen $M$, Iguchi $T$, Jobling $S$, Laufer $H$, LeBlanc $G A$, et al. An ecological assessment of bisphenol-a: evidence from comparative biology. Reprod Toxicol. 2007;24:225-39. https://doi.org/10.1016/j.reprotox.2007.05. 008.

19. Soderholm KJ, Mariotti A. BIS-GMA--based resins in dentistry: are they safe? J Am Dent Assoc. 1999;130:201-9. https://www.ncbi.nlm.nih.gov/pubmed/ 10036843

20. Olea N, Pulgar R, Perez P, Olea-Serrano F, Rivas A, Novillo-Fertrell A, et al. Estrogenicity of resin-based composites and sealants used in dentistry. Environ Health Perspect. 1996;104:298-305. http://www.ncbi.nlm.nih.gov/ pubmed/8919768

21. Imai Y, Watanabe M, Ohsaki A. Analysis of major components and bisphenol a in commercial Bis-GMA and Bis-GMA-based resins using high performance liquid chromatography. Dent Mater J. 2000;19:263-9. https://www.ncbi.nlm.nih.gov/pubmed/11218846

22. Atkinson JC, Diamond F, Eichmiller F, Selwitz R, Jones G. Stability of bisphenol a, triethylene-glycol dimethacrylate, and bisphenol a dimethacrylate in whole saliva. Dent Mater. 2002;18:128-35. http://www. ncbi.nlm.nih.gov/pubmed/11755591

23. Vandenberg LN, Colborn T, Hayes TB, Heindel JJ, Jacobs DR Jr, Lee DH, et al. Hormones and endocrine-disrupting chemicals: low-dose effects and nonmonotonic dose responses. Endocr Rev. 2012;33:378-455. https://doi.org/10.1210/er.2011-1050.

24. Richter CA, Birnbaum LS, Farabollini F, Newbold RR, Rubin BS, Talsness CE, et al. In vivo effects of bisphenol a in laboratory rodent studies. Reprod Toxicol. 2007;24:199-224. https://doi.org/10.1016/j.reprotox.2007.06.004.

25. Miyakoda HT, Masako T, Onodera SO, Takeda K. Passage of bisphenol a into the fetus of pregnant rat. J Health Sci. 1999:45:318-23.

26. Magnus P, Irgens LM, Haug K, Nystad W, Skjaerven R, Stoltenberg C, et al. Cohort profile: the Norwegian mother and child cohort study (MoBa). Int J Epidemiol. 2006;35:1146-50. https://doi.org/10.1093/ije/dyl170.

27. Magnus P, Birke C, Vejrup K, Haugan A, Alsaker E, Daltveit AK, et al. Cohort profile update: the Norwegian mother and child cohort study (MoBa). Int J Epidemiol. 2016; https://doi.org/10.1093/ije/dyw029.

28. Norwegian Institute of Public Health. Questionnaires from MoBa. 2005 [updated 15 September 2016]. https://www.fhi.no/en/studies/moba/forforskere-artikler/questionnaires-from-moba/. Accessed 15 Dec 2017.

29. Irgens LM. The medical birth registry of Norway. Epidemiological research and surveillance throughout 30 years. Acta Obstet Gynecol Scand. 2000;79:435-9. https://www.ncbi.nlm.nih.gov/pubmed/10857866

30. Fleischman AR, Oinuma M, Clark SL. Rethinking the definition of "term pregnancy". Obstet Gynecol. 2010;116:136-9. https://doi.org/10.1097/AOG. Ob013e3181e24f28.

31. Blencowe $H$, Cousens $S$, Oestergaard MZ, Chou D, Moller AB, Narwal R, et al. National, regional, and worldwide estimates of preterm birth rates in the year 2010 with time trends since 1990 for selected countries: a systematic analysis and implications. Lancet. 2012;379:2162-72. https://doi.org/10.1016/ S0140-6736(12)60820-4.

32. World Health Organization. WHO: recommended definitions, terminology and format for statistical tables related to the perinatal period and use of a new certificate for cause of perinatal deaths. Modifications recommended by FIGO as amended October 14, 1976. Acta Obstet Gynecol Scand. 1977; 56:247-53. https://www.ncbi.nlm.nih.gov/pubmed/560099

33. World Health Organization. Global Database on Body Mass Index. BMl classification 2007. 2007. http://www.who.int/. Accessed 22.11.2017.

34. Skjaerven R, Gjessing HK, Bakketeig LS. Birthweight by gestational age in Norway. Acta Obstet Gynecol Scand. 2000;79:440-9. https://www.ncbi.nlm. nih.gov/pubmed/10857867

35. Michalowicz BS, DiAngelis AJ, Novak MJ, Buchanan W, Papapanou PN, Mitchell DA, et al. Examining the safety of dental treatment in pregnant women. J Am Dent Assoc. 2008;139:685-95. https://www.ncbi.nlm.nih.gov/ pubmed/18519992

36. Nilsen RM, Vollset SE, Gjessing HK, Skjaerven R, Melve KK, Schreuder P, et al. Self-selection and bias in a large prospective pregnancy cohort in Norway. Paediatr Perinat Epidemiol. 2009;23:597-608. https://doi.org/10.1111/j.13653016.2009.01062.x
37. Berge $T L$, Lygre $G B$, Jonsson BA, Lindh $C H$, Bjorkman L. Bisphenol a concentration in human saliva related to dental polymer-based fillings. Clin Oral Investig. 2017; https://doi.org/10.1007/s00784-017-2055-9.

38. Kopperud SE, Tveit AB, Opdam NJ, Espelid I. Occlusal caries management: preferences among dentists in Norway. Caries Res. 2016;50:40-7. https://doi.org/10.1159/000442796.

39. Vidnes-Kopperud S, Tveit AB, Espelid I. Changes in the treatment concept for approximal caries from 1983 to 2009 in Norway. Caries Res. 2011;45:113-20. https://doi.org/10.1159/000324810.

40. Wang NJ. Tannhelseutvikling og bruk av tannrestaureringsmaterialer. In: Bruk av tannrestaureringsmaterialer i Norge IK-2652. 98-8. Oslo: Statens helsetilsyn; 1998. p. 69-74.

41. Selevan SG, Kimmel CA, Mendola P. Identifying critical windows of exposure for children's health. Environ Health Perspect. 2000;108(Suppl 3):451-5. https://www.ncbi.nlm.nih.gov/pubmed/10852844

42. Miller MT, Ventura L, Stromland K. Thalidomide and misoprostol: ophthalmologic manifestations and associations both expected and unexpected. Birth Defects Res A Clin Mol Teratol. 2009;85:667-76. https://doi.org/10.1002/bdra.20609.

43. Rogers JM, Kavlok RJ. Developmental toxicology. In: Klaassen CD, editor. Casarett and Doull's toxicology: the basic science of poisons. 7th ed. New York: McGraw-Hill; 2008. p. 417-8.

44. Gaffield ML, Gilbert BJ, Malvitz DM, Romaguera R. Oral health during pregnancy: An analysis of information collected by the pregnancy risk assessment monitoring system. J Am Dent Assoc. 2001;132:1009-16. https:// www.ncbi.nlm.nih.gov/pubmed/11480627

45. Norwegian Institute of Public Health. Research and data access from the Norwegian Mother and Child Cohort Study. 2010 [updated 11 January 2018]. https://www.fhi.no/div/datatilgang/. Accessed 19 Jan 2018.

46. Norwegian Institute of Public Health. MoBa study protocol. 2010 [updated October 2012]. https://www.fhi.no/globalassets/dokumenterfiler/moba/ dokumenter/moba-protokoll-norsk-versjon-oktober-2012-pdf.pdf. Accessed 19 Jan 2018.

\section{Ready to submit your research? Choose BMC and benefit from:}

- fast, convenient online submission

- thorough peer review by experienced researchers in your field

- rapid publication on acceptance

- support for research data, including large and complex data types

- gold Open Access which fosters wider collaboration and increased citations

- maximum visibility for your research: over $100 \mathrm{M}$ website views per year

At BMC, research is always in progress.

Learn more biomedcentral.com/submissions 